\title{
Performative Retrieving of Tradition for Socio-Political Intervention: A Study of the Protest Theatre of Dario Fo
}

\author{
Sohaib Alam ${ }^{1} \&$ Farhan Ahmad ${ }^{2}$ \\ ${ }^{1}$ Assistant Professor, Department of English, College of Sciences and Humanities, Prince \\ Sattam Bin Abdulaziz University, Saudi Arabia. ORCID: oooo-0oo2-9972-9357. \\ Email: s.alam@psau.edu.sa (Corresponding Author) \\ ${ }^{2}$ Assistant Professor, Department of English Studies, Faculty of Indian and Foreign \\ Languages, Akal University, Talwandi Sabo, India. ORCID: oooo-ooo1-5710-780o. \\ Email:farhan_eng@auts.ac.in
}

\begin{abstract}
Theatre provides Dario Fo with a unique vantage point through which he vents out his thoughts on issues of class, justice, equality and lays bare in his performances that are comic, derisive, and outspoken people's discomfort with the prevailing order. They are an indictment of the establishment's perceived apathy and neglect of the oppressed groups. He does not let the zany spirit of his performances to overshadow his art but redirects it in a constructive and meaningful way.
\end{abstract}

Keywords: performance, folklore, popular culture, hegemony, dissent

\section{Introduction}

Theatre inarguably for its capacity to engage in lively debates on intractable socio-political problems and its potency to propel change has been one of the most cherished art forms. From the earliest days of its origin theatre has been an enabling force against the unbridled power and a breeding ground for public dissent directed towards the power abusers.

Dario Fo is a marvellously talented theatre artist well known for his creative vigour and social commitment (purpose and creativity) combined to educate the uninformed populace on contemporary issues. Education of the distracted people had impelled him to do theatre with the motive to facilitate a well-informed debate on current affairs as he held that increasing informed public will be able to see itself more coherently and with a better understanding of the self and the society. He wanted to teach them the importance of knowing after realizing the fact that it is the only way out of the life of abasement and humiliation. Restoring dignity and protecting the interests of the downtrodden has been the central concern of the Fo. He seeks to challenge the dominant narratives of the Italian society developed and propagated to legitimize the subjugation of the native population exposing the way power structures seek to determine socio-political discourses which have ousted commoners from the mainstream and relegated them to an insignificant position. He leans on the dignitarian impulses of justice and equity invoking a progressive realization of the

(c) AesthetixMS 2020. This Open Access article is published under a Creative Commons Attribution Non-Commercial 4.0 International License (http://creativecommons.org/licenses/by-nc/4.o/), which permits non-commercial re-use, distribution, and reproduction in any medium, provided the original work is properly cited. For citation use the DOI. For commercial re-use, please contact editor@rupkatha.com. 
rights of the deprived groups using theatre as a weapon to safeguard their civil as well as political rights.

His art is socially committed and politically oriented. The socio-political and creative consciousness of Fo is shaped by his commitment to championing the cause of the underprivileged. The theatrical activity of Fo is indispensably aligned to the revolutionary struggle of the Italian masses against the social, political, and ecclesiastical powers. The expediency of his dramatic art can be judged by the role it plays in the political agitation and education of the marginalized community. His theatre is a tribute to all those who have a peripheral existence. "Fo's life and plays are a celebration of the oppressed, of those fighting against an unjust world" (Behan 200o, p. 141).

The revolutionary structure of Fo's plays is inspired by the militant working-class movement and the pressing demand for social, political, and historical change. He was well aware of the fact that revolution can be achieved only when peoples' minds are transformed. Political awareness, therefore, remains all-important to his agitational, indecent, and raucous performances. They contribute to the social, psychological, and intellectual emancipation of the suppressed class.

As a satirist and an invincible critic of contemporary Italian establishment, Fo is endowed with acute social sensibility and searing political commitment who according to Swedish Academy, "Emulates the jesters of the Middle Ages in scourging authority and upholding the dignity of the downtrodden. With a blend of laughter and gravity, he opens our eyes to abuses and injustices in society and also the wider historical perspective in which they can be placed" (Nobel Press Release 1997). The rapier wit and sombreness of his performances have dual functions of entertaining and instructing audiences on prevalent social discrepancies. Provoking people's conscience and to raise their consciousness is the overriding concern of Fo contextualized in the working-class struggle for hegemony. He uses theatre as a medium to intervene in the public life of Italy articulating the concerns of the beleaguered group. He speaks against the social, political, and cultural marginality of the minority groups i.e., workers, women, and students. His astute and resolute resistance to the ruling powers and his refusal to be cowed down by them shows Fo's commitment to the socially and politically excluded. His theatre thrives on flagrantly anti-establishment dissent.

To counter the cultural hegemony of the Italian upper-class he insists on the development of a proletarian culture by retrieving performance traditions of itinerant performers of the Middle Ages (giullari) and Harlequin of the Commedia dell' Arte. His adherence to tradition allows him to create a context that enables him to connect with the mass and their culture. His renewed interest in folk culture is not driven by some fatuous idea but he is very much conscious of his art and put it at the service of those offered least from the existing system. And he does so in their language to reach the wider population and to connect with larger social realities. His fascination with folk cultural forms is fuelled by the desire to restore the autonomy of socially, politically, and culturally marginalized as well as to promote indigenous values which have been perennially undermined by bourgeois imperatives creating the perception that deprived of our roots we can go nowhere. One of the reasons for his engagement with popular culture is to bring it back to acceptable standards. As put forward by Antonio Scuderi (2000), "Validating and ennobling folk culture has been a great part of Fo's mission and of the overall raison d'etre of his theatre" (p. 67). Besides, he used it as a weapon of choice to intervene in contemporary society and politics. He explores the possibility of tradition to make a creative intervention at a social, political, and artistic level. "Fo was content to ridicule bombast, hypocrisy, and petty oppression. The tradition of the popular theatre was sufficiently vibrant for his purposes and for his audience" (Farrell 1995, p. 320).

Although steeped in tradition Fo's theatrical expression is unequivocally modern. The antediluvian modus operandi in his works should not be misunderstood as being an archaic 
3 Performative Retrieving of Tradition for Socio-Political Intervention: A Study of the Protest Theatre of Dario Fo

expression. He is very modern in his outlook. The juxtaposition of past and present in his work helps to better understand both the prevailing social conditions and the pivotal role theatre can play in making people aware of those conditions. The present is addressed with the hindsight of the past for he espoused, the better we know the past the better we understand the present. Popular narratives are recreated in a constructive and meaningful way and bear significant relevance for present-day reality. They are supple and viable to the expression of modern themes. "Fo synthesizes past, present, and future concerns of society as he weds an appreciative sense of tradition with satirical but hilarious situations in which bureaucratic bunglings of immense proportions victimize the common people" (Aponte 1989, p. 542).

This unique combination of indigeneity and modernity in Fo sets him apart from his contemporaries and makes him an ingenious force in the theatre known for its outspokenness and anti-conformism.

\section{Objectives of the Study}

- This research proposes a study of the folkloric elements in Fo's select plays.

- The research emphasizes on how the folk narratives are harnessed to stimulate social conscience and to generate awareness.

- It intends to explore how theatre has been wielded by Fo as a weapon in the hegemonic struggle of the Italian working class.

- It stresses on the fact that human stories should not only be used to entertain people but also to instruct them.

- Tries to assess the impact his performances had left on his audiences in particular and on the society in general.

\section{Research Questions}

Although a significant amount of research has been furnished on different strands in the works of Fo, there remain some fundamental questions that need to be investigated in the course of this study.

- Whose interest does his theatre serve?

- How does he combine purpose and creativity?

- How does he discover the possibility of tradition to make a socio-political intervention?

- What has convinced him to engage with oral performative traditions?

- How far he has been successful in transforming his audiences?

\section{Methodology of the Study}

This study primarily engages with Fo's engagement with theatre as a synergetic creative expression of the feeling of dissent against the political and religious status quo of Italy. His theatre is a vivid representation of the lives of those that have been pushed to the margin, disempowered, and mistreated. Fo explores a variety of issues ranging from the dehumanization of the working class, to 
the bastardization of history and he does so in the tradition of medieval Giullari. The present study will be carried out with the help of the analysis of Fo's select plays to identify political and cultural constructs he postulates through these plays and to appreciate the revolutionary fervour of his theatre.

\section{Significance of the Study}

This research is significant in the sense that it will be a departure from previous studies done on Fo. The proposed research demonstrates that art, whatsoever, contributes to human knowledge and understanding. It gives people a sense of purpose and makes them responsible citizens. Art provides them with a unique perspective to look at things and refines their senses. It propagates human values and defines the truth of our life and society. Art is a way to understand and change reality, a medium of promoting social and civilizational values, and an occasion for social interaction.

\section{Discussion}

Bound up with and reinforced by Fo's performances is the struggle of Italian masses for social justice through respecting and venerating an antique past. Vehement anti-establishment tirades seething with amoral comedies against hard-headed bourgeoisie and Papacy characterize his performances. He is intent on presenting the abysmal socio-economic condition of the fringe groups motivated by the desire to change it by raising awareness of their dehumanized state. His performances are designed to empower the powerless. They hold his important views on politics, history, and culture which shape the worldview and have been crucial in the human struggle for power.

His performances provoke resistance to the precarious survival of the weaker section of society and actively engage in the campaign for their rights whose freedom is dependent on the whims of others. They reflect the lived reality of Italian underdogs venting out outrage against their peripheral existence and are a powerful vindication of Fo's conviction determined by his conscious desire to develop a counter-hegemonic discourse against invasive powers of the state launching a scathing attack on the government accusing them of caring only for their interests and abusing their statutory functions and powers by abetting or perpetrating injustice. They disinterestedly pursue the truth about power politics to rid the people of oppression instead of rationalizing or justifying their position and are dedicated to the cause of social justice by upholding civil and personal liberty of the oppressed.

As a critique of ruling dispensation these performances deplore the unhappy states of affairs expressing a deep sense of dissatisfaction with the status quo in Italy. Fo is hell-bent to expose the social, political, moral, and religious hypocrisy of the Italian establishment. He is unsparing in his criticism of the authority and spirited in espousing the workers' cause. He felt acutely the necessity of a rediscovery of the past ensuing after the disillusionment of modern times that will give a sense of solidity and empowerment to the socially outcast people making them realize that they have the credentials to shape history and not just be possibly shaped by it. His performances are inspired by a genuine spirit of philanthropy ridiculing the liberal vision of democracy and development as well as religious consolations. They entail acute socio-political insights and instinctive dissent functional in the struggle for social change. Fo aims at collective communication contributing to people's knowledge and understanding of contemporary events by incorporating serious political discussions in his performances. 
5 Performative Retrieving of Tradition for Socio-Political Intervention: A Study of the Protest Theatre of Dario Fo

In addition to bringing theatre to the people, Fo was committed to a bloodless revolution of the proletariat. His own political convictions had moved progressively left from Marxism to Maoism. By exposing his view of the evils of contemporary society, especially the corruption of the Italian government, Fo believed he could awaken the people to the need for a radical change in government. (Sogliuzzo 1972, p. 74)

The comic performances of Fo do not simply intend to entertain audiences but outline significant lines of thought about the liberation of repressed humanity through a critique of the notions of common sense which he cogitates is a construct of power relations ineluctably linked to and perpetuated by various social practices and institutions. They are the breeding ground of important civil conversations on issues related to class struggle, politics, religion, history, and culture as he wants to discern workers from the mercenary mob with no ideology. He through his performances challenges the stale assumptions that undergird so many cultural institutions of Italy trying to push back the ruling class hegemony and shaping a new working-class consciousness with the purpose to change their way of looking at things. He uses theatre which is an embodiment of his animated spirit as a weapon to represent those in need of representation. He is brash and insulting in his approach to deal with the political class questioning the divisive and fascist ideology of the government. He wants equal participation of each group vested in Italian democracy. He uses theatre as a tool to instigate protest against deep-rooted social prejudice which has pushed the Italian working classes into a pit of obscurity.

Thus, his performances are not only a dramatic event but an institution centred on the education of the proletariats which has been a central motive for him. They present a complex weave of present and past and an astute mix of laughter and anger catering to the benign vision of a free democratic nation-state insisting that an egalitarian society is dependent on the spread of democratic principles and acute political awareness trying to wake them up from the stupor of unconsciousness. It is pointless to aspire for liberty if one's mind is servile. They represent the longstanding and intractable predicament of the working class Italians and are an extraordinary expression of all that he found intolerable. They carry embittered criticism of the liberal-minded conspirators who maintain their power by manipulating the public view. Their concern for people is merely a social façade. These performances also bear resistance to the servile collaboration of the Church with the despotic authorities in exploiting the subordinated groups.

Fo's unwavering support to the cause of the oppressed explains his position. His unprecedented popularity rests on his opposition to the status quo and his take on the Italian establishment careless of the rights and dignity of the poor. His devoutness to address their concerns resulted in the prodigious output of plays fomenting social and political change. These plays are not merely the reflection of the complex political situation in Italy but a critical analysis of them reveals how his presentation changed with each new political development. His theatre plays an active part in educating the workers and his stress on their education is invested with a sense of intellectual duty. Fo, the rebel and the satirist has been drawn into the huge task of educating the proletariats because he thinks them as victims of a clever propaganda campaign which segregated them from the Italian mainstream. His performances play a key role in the construction and dissemination of his political discourses which are mainly concerned with the liberation of socially, politically, economically, and culturally marginalized groups. He wants to turn them into an independent class who instead of depending on the goodwill of their masters should find their way to reaffirm themselves.

His performances have a flair of farce and politics. The action constantly shifts from political facts and figures, nitty-gritty realism, storytelling, clowning, miming, and surrealism. The 
exhilarating spirit of farce in his plays is used as a liberating device of the repressed mentality. He does not allow the audience to settle through the dramatization of grim socio-political realities which are profoundly conditioned by social and political context. This alignment of farce and political commitment runs throughout his performances. Politics can never be separated from his theatre which is a well-documented description of contemporary socio-political conditions in Italy. Inevitably linked to the fabric of society and performed as a protest against the oppressiveness of the Church and the state his performances contribute greatly to the cause of the exploited community. He denounced the backwardness and bleakness of Italian public life holding the powerful accountable for this unjustified social division where one section has access to all kinds of privileges while the other remains deprived even of basic social amenities. Fo strongly detests this abasement and humiliation of the working-class community.

His theatre is a documentation of the plight of the poor and capitalist injustice thrusting against all forms of oppression. He unmistakably saw relationships of whatever kind as power struggles in which one side must eventually take authority. The phenomenon of capitalism turned the workers into a class struggling for revolution. The provocative performances of Fo sought to revolutionize popular consciousness against endemic political corruption and stalemate of Italian democracy. His performances assess the sincerity of the political motives of the politicians. He used theatre as a vehicle to achieve his ambitious project of transforming the wretched condition of the Italian workers and other subordinate classes. He wants to make them aware of the larger sociopolitical reality which is often complex and fraught. He questions the hegemony of the ruling class and promotes an alternative proletarian hegemony. Fo's forthright political views and his unabashed style to censure the authority, especially on issues affecting civil society make him one of the leading proponents of anti-establishment theatre.

The creative genius of Fo is fuelled by Italian oral tradition. He draws on the Latin farces of Plautus, the subversive performances of the medieval giullari, the dialect narratives of the fabulatori, and the improvised comedies of the Renaissance Commedia dell'Arte. His theatre is a collage of diverse techniques appropriated from popular folk tradition in defiance with conventional theatrical forms notwithstanding his early association with the bourgeois theatre. The amazing combination of farce and politics, laughter and anger, fact and fiction as well as tradition and modernity in Fo's plays evolved a completely new paradigm of theatre which is always open for improvisation at intellectual, emotional, and performance levels. Fo is revolutionary in both sense thematically and structurally. Giving her opinion on his unique style Franca Rame (1994) states:

He has a constant inventiveness and is always lively and young, never banal and obvious. His scripts are always technically perfect, never boring or tiresome. What amazes me most of all is that when he writes, he always keeps the structure of his text entirely open, he doesn't build in advance a complete framework. He invents dialogue based on a paradoxical or a real situation and goes on from there by virtue of some kind of natural, geometric logic, inventing conflicts that find their solutions in one gag after another in correspondence with a parallel political theme, a political theme which must be clear and didactic. You are moved and you laugh, but above all, you are made to think, realize, and develop your understanding of everyday events that had before escaped your attention. (p. xxix)

Culture occupies a central place in Fo's performances because he perceives it as an apparatus used for the exercise of power. It is one of the various institutions developed to sustain power relations. "Culture is a mode of domination. Without a counter-hegemonic culture, there can be no revolution" (Stephanson, Salvioni, and Fo 1986-1987, p. 164). Art and literature are viewed as forms of cultural practice. His overriding preoccupation with vernacular culture and language shows his 
7 Performative Retrieving of Tradition for Socio-Political Intervention: A Study of the Protest Theatre of Dario Fo

concern for the people living on margins and its retrieval justifies his struggle against the pervasive dominance of the consumerist culture. He borrows a great deal from popular literature appropriating the mad vitality and exuberance of folk performances. His performances are a weave of colloquial expression and mannerism suggestive of popular culture. These are the qualities that give his theatre extraordinary vitality and edge. He uses theatre as a medium of cultural expression of the proletariat.

The popular and political thrust of Fo's theatre is prompted by medieval itinerant performers (giullari) who opposed the people in positions of power through the medium of satire using laughter as a technique of provocation and subversion. Harlequin, the zany figure from Commedia dell'Arte is another chief inspiration for Fo. His ridiculousness and zaniness although scandalous indeed, have the purpose of provoking people's conscience and making them politically conscious and mature. "Fo's performance is an allegory of rebellion camouflaged behind a mask a crude buffoonery" (Jenkins 1986, p. 173). His performances are an act of resistance to the forces of allround control and convey a deep sense of outrage against the established order for not taking a stand on the matters of liberty, dignity, and security of its people. They are the voices of dissent against large-scale infraction of human rights by a sovereign state and its sectarian approach to a substantial section of society. Oppressed and marginalized are the locus of his performances which are the epitome of their living experiences. They are arranged into a forum of public discourse debating and discussing the matters of social, political, religious, historical, and cultural importance. Commenting on his theatre Fo (1994) says:

The type of theatre which I would like to propose has two directions. First, theatre as retrieval of medieval peasant culture, linked to the important moment of our history and tied up with the class struggle, religious conflicts, and so on. Second, theatre as a counterinformation about the events which occur in our social reality: exposing the violence of the system, police repression, and using the grotesque and satire in such a way that the comedian's distorting lens enables the public to experience a synthesizing, didactic vision, which means giving them alternatives or moments critical reflection, etc.

Another fundamental aspect of this type of theatre is that it is the result of debate: it doesn't rain down vertically on people's heads, but when it is performed it has already been digested and debated and has even created conflicts and arguments. This means that the audience is directly involved in the play, modifying it and suggesting changes -the play is part of the audience's reality. (p. 206-207)

His deliberate choice to work within the popular tradition and his intent on debunking the myth of the superiority of the official culture shows his solidarity with the marginalized culture which turns up one of the major themes in his plays. He is against this ostracization and demonization of the plebeian culture which has always been looked down upon by the dominant class. Fo's refashioning of the traditional oral narratives is an attempt at the representation of history that is from a popular perspective opposed to the dominant perspective. His recouping of the past is an assertion of the interests of the culturally marginalized group. Official vs. the popular is the major thrust of his theatre.

Fo's theatre works towards rectifying this bastardization of history and denigration of popular culture by presenting history from a subaltern point of view and by putting back what official culture conveniently left out. His mission is to restore the dignity of the downtrodden masses with his own interpretation of history. (Scuderi 2000, p. 28) 
The exceptional blend of humor and satire in Fo's theatre has been wielded as a weapon to drag down the authority and to make people feel liberated. The grotesque humor of his plays transcends to the level of prickliness at the imbalances of power. Fo's brazen scurrility and the outrageous nature of his performances is sought not to simply generate laughter, but as a provocative mechanism to awaken the audiences to reflect on their condition, turning him into one of the greatest provocateurs of the twentieth century. So, for a real appreciation of his theatre and the significant role it played in shaping people's opinions, one has to look beyond the entertainment that it offers. "Fo insists on the importance of comic-grotesque element in theatre, both as part of the patrimony of genuine popular culture and as a basic tool for raising political consciousness" (Cowan 1975, p. 108).

The ideological function of Fo's theatre concurs with Antonio Gramsci that is to uphold the dignity of the downtrodden and to push forth the question of social justice and equality. His theatre grows out of the experiences of the oppressed group, i.e. the Italian working class and the peasants, articulating the point of view of that group.

Theatre provides Fo with a platform to engage in a debate over values, norms, the text of traditions and politics of culture to create a set of people who can transform themselves into a consolidated group with legitimate rights and interests. Added layers of modernity over crusted layers of outmoded structures helps his theatre to rediscover its strength in subverting the obstinate structures of class-based discrimination so deeply entrenched in state and civil society. Recovery of the past is an enabling provision of a context that obliges Fo, to comment on exigent problems, and to package himself as the people's voice. In Farrell's words (2001), “The articulate representative of non-articulate culture" (p. 77). The expediency of theatre to shape public opinion has been ingeniously exploited by Fo who strongly felt the need for change in attitudes and mindsets of people and the need to think outside of the customary framework giving them a reason to fight for their equitable space in Italian society. So production of knowledge is one of the predominant concerns of the playwright. His comedies are not the comedies of leisure but serve a polemical purpose of educating the audiences at crucial socio-economic, political, religious, cultural, and historical issues. "The production of knowledge useful to the oppressed has been one of Dario Fo's foremost concerns throughout his career" (Piccolo 1988, p. 131).

The symbiosis of popular and political is one of the most striking features of Fo's theatre. His appropriation of the popular performative traditions to subvert the political and religious status quo of Italy bears on the cultural politics of Fo. He was more and more convinced with the subversive power of the popular culture which does not only provide him with a context but also with a dialectical method to deal with the current state of affairs and to combat the hegemonic powers. In Fo's own words, "I think popular is subversive in itself. Its basic themes lend themselves to that: hunger, the tragedy of having to survive, the problem of dignity, of liberty. Just speaking about these issues is subversive" (Stephanson, Salvioni, and Fo 1986-1987, p. 163).

This intersection of past and present, tradition and modernity, education and entertainment as well as politics and aesthetics is all according to Gloria Pastorino (2002) "Part of the evolution of an artist whose first preoccupation has been to create a kind of theatre that could truly involve its audience in its discourse and make it think" (p. 29).

The revolutionary optimism of Fo gets best expressed through his political satires which is one of the major mediums of his artistic expression. But what is important about them is their cultural rootedness in the farcical tradition of the popular entertainment employed as an instrument of bringing about social change. "The most powerful political weapon in Fo's theatrical armoury is farce" (Hirst 1989, p. 38). 
9 Performative Retrieving of Tradition for Socio-Political Intervention: A Study of the Protest Theatre of Dario Fo

In Accidental Death of an Anarchist, the target of Fo's pungent satire are the police and the state for their coordinated crime. He treats them with scorn for their brutal act of violence perpetrated at Pinelli alleged to have conspired in blowing up the Bank of Agriculture at Milan which left at least 16 dead and dozens wounded. Many arrests have been made alongside Pinelli whose case became a cause celebre in entire Italy. The play provides counter information into the mysterious death of Pinelli under police custody which triggered the nationwide protest. Police reported his death a suicide which was doubted by many. And how a person like Fo who is so concerned with humanity and social justice could have been imagined to remain silent. This incident provided him with food for thought for this play. Fo reconstructs the whole incident showing inconsistency in police records which confirms that his death was not a suicide but a coldblooded murder for which the police should be held responsible. He berates them for their vicious abuse of power.

In addition to providing information into the case of Pinelli, the play has deeper political implications about realpolitik raising concerns over the rapid radicalization of Italian politics and state-sponsored terrorism. It was a bitter ironic reaction to the 'strategy of tension' adopted by the Right-wing to get political mileage over the Left and to cover up its corruption.

The play is an ingenious mixture of laughter and satire wielded as a tool of socio-political intervention. By inventing the famous character of Maniac who has popular resonances Fo exposes the truth of the hypocritical system and its affiliates. "Accidental Death abounds with elements of popular theatre, in the sense of a people's theatre that not only goes beyond mere escapist entertainment and broad public appeal but also seeks to bring to the fore felt the resentment of the populace" (Chimwenje 2005, p. 24). For him, madness is a method, a mode of dissent against the forces of the status quo. Fo's maniac shares a great deal with the Harlequin and the Lord of the Misrule. He enjoys a fool's license to speak out the truth often fabricated and manipulated by the powerful to serve their interest. Lunacy is cloaked with reason and resistance. Chimwenje's description of the Maniac gives a clearer picture of his decisive role in the play. He argues:

Fo's conceptualization of the Maniac goes beyond mere theatrical artifice. In the Maniac, we have a highly technically stretching role. Despite being a certified lunatic, the Maniac is a resourceful, tenacious, and calculating character; his is a multi-layered, chameleon-like personality, very elusive and unpredictable. The histrionic and creative resourcefulness that Fo invests in the Maniac serves the playwright very effectively insofar as the play's assault on institutional dishonesty and social justice is concerned. (Chimwenje 2005, p. 26)

It is called an all-purpose protest play questioning every form of authoritarianism and injustice.

Can't Pay! Won't Pay!, gives expression to public disquiet over the soaring prices of food, housing, electricity, and transportation corollary of the great economic depression Italy had undergone in the late 7os. The period was also marked by rising levels of unemployment which affected millions of lives exclusively the inhabitants of periphery who bore the brunt of the recession and struggled to make their ends meet. Observing no great improvement in the situation and absence of any remedial measure taken up by the government the mobilized masses took the matter in their hands. To register their protest against the continual increase in the price of goods and services they decided to pay less or pay nothing. This was known as the self-autoriduzione (selfreduction) movement; a civil disobedience movement against inflationary prices. However, Fo's approach is not restricted only to the expression of widespread public discontent in the face of this economic crisis but he successfully creates a conflict between the revolutionary and the evolutionary 
processes of bringing about change. The subsequent conversation between the Sergeant and Giovanni vividly projects this conflict.

Giovanni: Well, then you've got your democratic procedure. Laws can be reformed, you know.

Sergeant: Oh really? Reform? Reform? Don't make me laugh. We've been hearing that for 30 years. Reforms. No mate. If people want change they'll have to do it themselves. They'll have to melt the shackles of capitalism and the iron fist of oppression with the boiling blood of Karl Marx. Where the broom does not reach, the dust will not vanish of itself. Know what I mean? (Fo 1994, p. 21)

Fo is very much disheartened by the passive stance of the Communist Party against the workers' exploitation and its non-participation in the movements of agitations launched by them. He finds fault with both the political parties for the appalling socio-economic condition of the working class. This particular play was performed as a revolt against bureaucratic control of the right-wing and mediocrity of the left. One of the central themes in the play is hunger which has been used as a metaphor signifying that people are hungry not just for food but also for justice and dignity. The play is an exceptional blend of farce, politics, and social realism that turns it into a proletarian carnival. The farcical structure of the play is a source of madcap humor at the same time it allows Fo to dispose of the pressing concerns of his age.

Trumpets and Raspberries exposes the façade of Italian politics and duplicity of prominent politicians of the day. The play evinces the government's attitude towards terrorism by inferring the murder of Aldo Moro, the famous Christian Democrat politician who was sacrificed by his associates in the name of firm government as they assumed any sort of compromise with the terrorists as a mark of weakness. Although there is no direct reference to the Moro incident in the play it is implied through Angelli's case. But unlike Moro, Angelli's life is bargained with the release of political prisoners because capitalists represent the real power. They are the ones who run the state and control power relations by controlling the production and its distribution in the market. Government and its related institutions are just their aides helping them to maintain their power. As the Double states, "The sacred laws of this state... the economic state... are written on watermarked paper money. So the government, state, and institutions are nothing other than supporting services, for the real power, which is economic power" (Fo 1992, p. 309).

Once again Fo's comic inventiveness comes into the play as he succeeds to create a farcical situation arising out of the confusion of misrecognition which helps him to disclose the clandestine activities of government and its functionaries. For instance, completely disfigured in a terrorist attack Angelli is taken to hospital where he is mistakenly identified as one of his staff and is subjected to a police interrogation on the suspicion of being involved with a terrorist organization. Shortly after they call off the investigation when the suspect starts making startling revelations about their covert operations. The following extract from the play makes it clearer.

Inspector: Listen, would you mind if we get back to our little chat?

Double: Yes, let's begin again... You were asking me if... I remember the traffic of arms... and who were they aimed for? Vaguely... I remember the word... Wing, plot, right. Right-Wing Plot. That's right. And the word... 'destabilize'... But I didn't agree... but there was somebody... police, I think.

Examining Magistrate: Police? Which police?

Double: Well, I don't remember... May be ours... 
11 Performative Retrieving of Tradition for Socio-Political Intervention: A Study of the Protest Theatre of Dario Fo

Examining magistrate: Italian Police? Special Branch? Secret services?

Double: Very Secret... Special services... One time they were on the point of exposing them... I knew about it... I was scared they'd implicate me too... Ah, now I remember the trial... Generals, ministers... then everything was exposed... and then covered up again! Whitewash.

Inspector: Whitewash?

Policeman: Generals... ministers... I didn't quite catch that. What was it he said before 'whitewash'?

Inspector: Don't write that down, you pillock. Rub it out. Rub it all out!

Examining magistrate: No, not everything. Only from police onwards...

Double: Ah, now, that period I remember well, really clearly... All the big-nobs, all their names... There was even an admiral involved... a judge... a minister...

Examining Magistrate: Will you stop remembering? (Fo 1992, p. 251-252)

The play is a quintessence of farce and politics revealing the hand-in-glove workings of politicians and corporations. It nudges debate on the profound question of political correctness and political morality.

Dialectically opposed to Fo's political satires are his monologues which he has developed over the years to convey a more general and universal type of knowledge in contrast to the more specific response evoked through the earlier type. They show Fo's maturity as an artist and add variety to his theatre.

Mistero buffo (Comic Mysteries; 1969), is regarded not only the best among Fo's extensive oeuvre but also the best among his monologues and his satires on religion. It is a collection of monologues which are a scandalous representation of matters sacred appropriated and used against the Church. It is a satire directed at the supreme authority of the Church being subordinated to the questions of political convenience. He objects the ultimate superiority of religious masters. The amoral tone does not legitimize any form of brutality rejecting all authority outrightly and considering the position of the Church as an oppressive temporal power. His attacks on the Church were never attacks on religion, but on the use of religion to hold people in thrall. He believes in the religion of humanity enlisted to a political cause.

Fo's radical reimagining of the Biblical stories is an attempt at the subversion of the official narrative and its retelling from people's point of view, i.e. the peasant, the giullare, the drunkard, the madwoman, and the fool. "His specific aim in Mistero Buffo is to rewrite history, or, rather, to retell historical events from another point of view: that of the people, so challenging and subverting the official view" (Hirst 1989, p. 119). Dario Fo like a historian develops a narrative told from a popular perspective. He wants to affirm that alongside the dominant perspective there exists an alternative perspective that must be honoured and protected. He firmly believes in giving voice to the voiceless, to the people who are not allowed to have an opinion. The play articulates the concerns of the socially and politically excluded allowing less heard voice an opportunity to speak out, to be heard.

It also showcases the technical virtuosity of Fo and his maturity as a theatre artist. The amalgam of sacred and secular, tradition and modernity, storytelling and clowning, dialogues and miming, turns Mistero Buffo into a classic comedy with its roots in popular history and culture. 
Fo's dialectics of oppression, revolution, and liberation continue in Il fabulazzo osceno (Obscene Fables; 1982). The play is a cluster of three monologues which as the title suggests are obscene and used as a weapon of liberation against the forces of coercion. Fo's treatment of the subjects of sex and scatology is a celebration of festive folk culture almost defunct which somehow has managed to survive the hostility of the ruling elites and was preserved and carried forward by the troubadours of oral tradition; the tradition Fo falls on. "The 'Obscene Fables' reveal Fo in a more 'scabrous' vein than Mistero Buffo, exploring a more Rabelaisian vein of satire than the religious subjects of the earlier texts. It also emphasizes Fo's direct link with the scatological 'grotesque realism' and the 'world upside down' of medieval carnival" (Mitchell 1999, p. 38). This work of Fo creates a new vocabulary of protest.

La storia della tigre e alter storie (The Story of the Tiger; 1978) belongs to the same genre of monologues but puts forth completely a new perspective. Albeit, the play relatively lacks in political vigour and revolutionary spirit of his satirical farces it is a sensitive barometer to the changing political climate in Italy in the 8os. Fo was an acute observer of everyday realities and used theatre as an outlet to expound them. He borrows the story of the play from a Chinese parable where Tiger stands for self-belief and self-determination. Fo emphasizes that instead of vesting their interests to get represented by any political party or to be bound up with its line of thought, people must develop their own ideology to be guided by it. He warns them of the provocative rhetoric of the political parties and advises them to be self-reliant. The animal and human relationship are very important in the play as it helps them to connect with their prehistoric roots.

Fo feels strongly about the importance of people establishing a connection with their history, a point made on numerous occasions. Having the villagers disguised themselves as tigers alludes to his take on the origin of the use of masks, specifically animal disguises, by prehistoric hunters. (Scuderi 2004, p. 76)

\section{Conclusion}

Closely tied to the working class struggle his theatre voices their needs and problems. He seeks to transform them into an empowered class using theatre as a catalyst for this transformation. The ideological underpinnings of his performances which contain his views on power are exclusively Gramscian. They interrogate into the dominant power narratives to bring out the truth of the hypocritical system and sub-serve the playwright's purpose of constructing a counter-narrative about the rights, dignity, and autonomy of the underprivileged. They represent the interests of the dispossessed supporting their inclusion and accommodation in the ordering of national affairs thus helping them out from social and political disenfranchisement.

Fo fights on all fronts for those suffering from political oppression, economic exploitation, and social degradation. The revolutionary structure of his performances and his uncoerced allegiance to the plebeian culture is a surge of reaction against bourgeois values and aesthetics and a mark of the celebration of Italy's traditional past. They offer a way of thinking about Italian society, its class struggle, and its extreme politics. They voice an underlined discomfort against the authoritarian exercise of power and excesses of the state. He uses the past to examine the fault lines of contemporary power structure preaching freedom and democracy through his rich oeuvre. Fo has been an unequivocal voice of dissent against every form of injustice. He does not miss any opportunity of dragging down the authorities. But at the same time, he is very conscious of his art and avoids reducing it to political rhetoric maintaining a perfect balance between his politics and poetics. His theatre swings alarmingly between credulity and disbelief, compassion and cruel 
1 Performative Retrieving of Tradition for Socio-Political Intervention: A Study of the Protest Theatre of Dario Fo

mockery, outspokenness, and resilience to power abuse. "Dario Fo is a performance artist and a playwright whose comically costumed message, beware institutional power, has been heard around the world. Both his comedy and his message are nourishing our theatre today" (Aponte 1989, p. 542).

\section{References}

Aponte, M. D. (1989). From Italian Roots to American Relevance: The Remarkable Theatre of Dario Fo. Modern Drama. Vol. 32(4), 532-544.

Behan, T. (2000). Dario Fo: Revolutionary Theatre. London: Pluto Press.

Chimwenje, J. (2005). Bringing Pus to the Surface: Dario Fo and the Dramaturgy of Irreverence. J. Humanit. Vol. 19, 19-38.

Cowan, S. (1975). The Throw-Away Theatre of Dario Fo. The Drama Review. Vol. 19(2), 102-113.

Dario, Fo. Nobel Prize. Org. Nobel Media AB 2020. Mon. 20 Apr 2020. <https://www.nobelprize.org/prizes/literature/1997/press-release/>

Fo, D. (1994). Dario Fo: Plays Two. Ed. Stuart Hood. London: Methuen Drama.

---. (19994). Can't Pay? Won't Pay! Trans. Lino Pertile. London: Methuen Drama.

---. (1992). Trumpets and Raspberries. Trans. R.C. McAvoy and A.M. Giugni. London: Methuen Drama.

---. (2004). The Peasant's Bible: And, The Story of the Tiger. Trans. Ron Jenkins. New York: Grove Press.

---. (1994). From Retrieving the Past, Exposing the Present (1978). In Richard D. (Ed.). Twentieth-Century Theatre: A Sourcebook. (pp. 204-208). London: Routledge.

Farrell, J. (2001). Dario Fo and Franca Rame: Harlequins of the Revolution. London: Methuen.

---. (1995). Fo and Feydeau: Is Farce a Laughing Matter. Italica. Vol. 72(3), 307-322.

Hirst, D. L. (1989). Dario Fo and Franca Rame. London: Macmillan.

Jenkins, R. (1986). Dario Fo: The Roar of Clown. The Drama Review. Vol. 30(1), 171-179.

Mitchell, T. (1999). Dario Fo: People's Court Jester. London: Methuen.

Pastorino, G. (2002). Playing With Authority: The Theatre of Dario Fo. PhD thesis, Harvard University, US.

Piccolo, P. (1988). Dario Fo's Giullarate: Dialogic Parables in the Service of the Oppressed. Italica. Vol. 65(2), 131-143.

Pizza, M. “Re: Obscene Fables”. Message to Farhan Ahmad. 7 Nov 2017. Email.

Scuderi, A. (200o). Dario Fo and Oral Tradition: Creating a Thematic Context. OralTradition. Vol. 15(1), 2638.

---. (2004). The Cooked and the Raw: Zoomorphic Symbolism in Dario Fo's Giullarate. The Modern Language Review. Vol. 99(1), 65-76.

Stephanson, A. et al. (1986-1987). A Short Interview with Dari Fo. Social Text. (16), 162-167.

Sogliuzzo, R. A. (1972). Dario Fo: Puppets for Proletariat Revolution. The Drama Review. Vol. 16(3), 71-77. 